Калюжний В. Л. Левченко В. М. Марчук К. Л. Дементсєв М. В.

\title{
СИЛОВІ РЕЖИМИ ТА НАПРУЖЕНО-ДЕФОРМОВАНИЙ СТАН ПРИ ХОЛОДНОМУ ВИДАВЛЮВАННІ ПРЯМОКУТНОЇ ПОРОЖНИНИ В КВАДРАТНІЙ ЗАГОТОВЦ
}

Квадратні і прямокутні коробки достатньо розповсюджені деталі, які виготовляють холодним зворотним видавлюванням із пластичних сталей і кольорових металів. При цьому вироби можуть бути з постійною, або змінною по периметру, товщиною стінки. При проектуванні технології видавлювання коробок мають місце обмеження для отримання виробів за один перехід - по товщині стінки і дна, а також на максимальну глибину вдавлювання пуансона в заготовку $[1,2]$. Як показали експериментальні дослідження і виробничий досвід, при холодному видавлюванні коробчастих виробів має місце суттєва нерівномірність деформацій, яка приводить до утворення виступів на торцях стінок. Тому потрібна додаткова операція підрізання торців стінок. В літературних джерелах по проектуванню технології видавлювання коробок мають місце дані по визначенню зусилля видавлювання [3]. Практично відсутні відомості по встановленню кінцевих форм і розмірів коробчастих виробів, зміцнення здеформованого металу. Для розроблення технології холодного видавлювання коробчастих виробів потрібне доопрацювання технологічних і конструктивних параметрів трудомісткими 3 великою вартістю експериментальними роботами. Використання математичних моделей на основі методу скінченних елементів (МСE) вказаних процесів дозволяє визначити силові режими видавлювання, розподіли питомих зусиль на деформуючому інструменті і встановити кінцеві форми і розміри виробів [4-7]. Однак в теперішній час актуальними є задачі по встановленню зусиль виймання пуансонів із здеформованих заготовок, виштовхування виробів 3 матриць та виявленню теплового ефекту при холодному формоутворенні коробок.

Метою роботи $\epsilon$ встановлення за допомогою метода скінченних елементів силових режимів видавлювання, виймання пуансонів із здеформованих заготовок, виштовхування виробів із матриць та напружено-деформованого стану здеформованого металу при холодному видавлюванні прямокутних порожнин у квадратних заготовках.

На рис. 1 у двох проекціях приведено схему видавлювання коробки з позначеннями. Ліворуч від вісі $y$ показане положення перед видавлюванням, праворуч - в процесі видавлювання. Вихідна квадратна заготовка 1 встановлена в матриці 2 на виштовхувачі 3. Зусилля видавлювання $P$ прикладається за допомогою пуансона 4 , який рухається зі швидкістю $V_{0}$. Із заготовки отримується виріб 5 з прямокутною порожниною із товщиною стінок $S_{1}$ i $S_{2}$.

Розрахунок параметрів видавлювання проводили шляхом моделювання з використанням програми DEFORM. Метал заготовки із алюмінію Al-2024 3 розмірами $\mathrm{Cx} B \mathrm{xH}=20 \times 20 \times 20$ міліметрів (мм) вважався пружно-пластичним. Це дозволяє визначити кінцеві розміри та форму виробу після деформування, а також проаналізувати процеси виймання пуансона із здеформованої заготовки та виштовхування виробу із матриці. Враховано тепловий ефект при холодній формозміні, вплив тертя по Кулону із коефіцієнтом тертя $\mu=0,08$ та швидкість деформування $\mathrm{V}_{0}=4$ мм/сек. Форма $\mathrm{i}$ розміри пуансона показані на рис. 2: $c \mathrm{x} b=12 \times 16 \mathrm{\text {м};} r=R=2 \mathrm{\text {м};} \alpha=7^{\circ} ; z=0,15 \mathrm{mм} ; l=2$ мм. Товщини стінок складають $S_{1}=4$ мм, $S_{2}=2$ мм. 


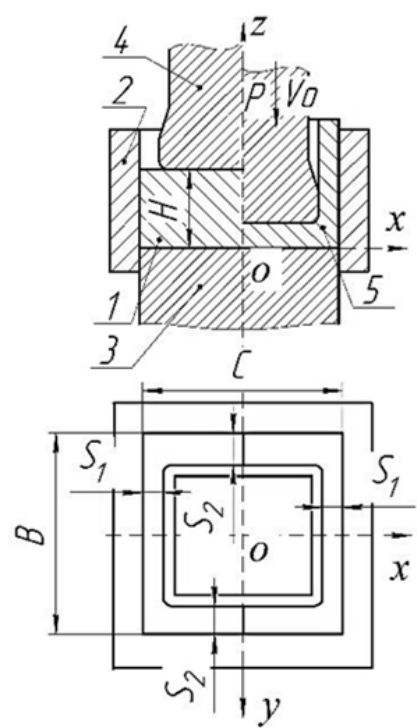

Рис. 1. Схема видавлювання коробки

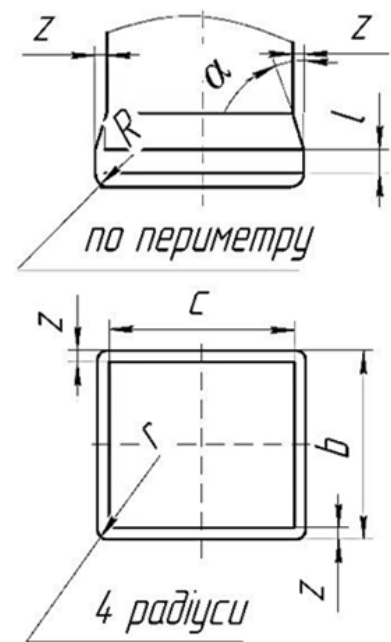

Рис. 2. Схема пуансона з розмірами

На рис. 3 приведені в розрізі розрахункові схеми. Схема на початку видавлювання показана на рис. 3, а. Заготовка 1 встановлена в матриці 2 на виштовхувачі 3. Деформування виконується шляхом опускання пуансона 4 і отримується виріб 5 (рис. 3, б). Схема після виймання пуансона із здеформованої заготовки зображена на рис. 3в, а після виштовхування виробу з матриці - на рис. Зд.

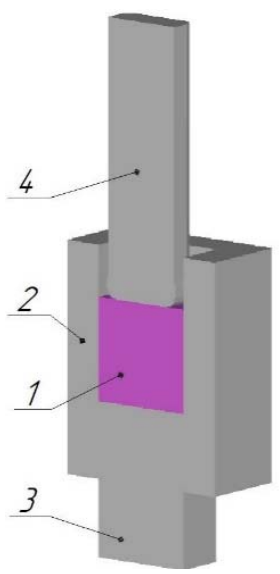

a

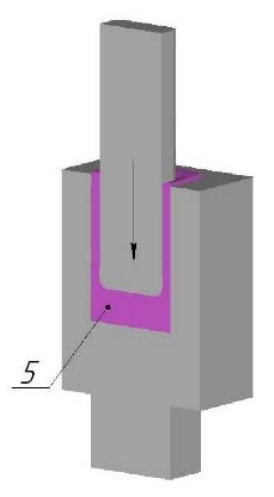

б

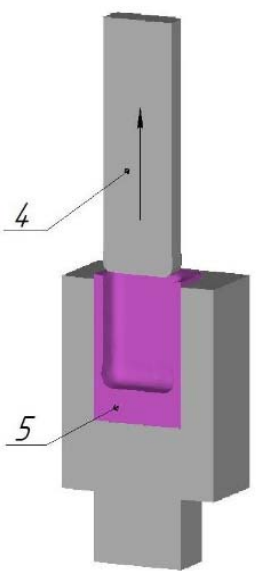

B

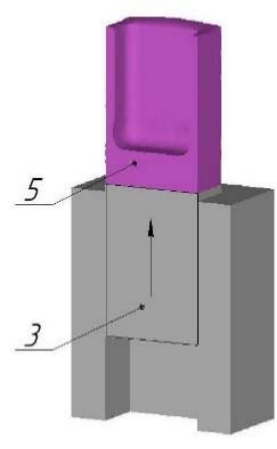

$\Gamma$

Рис. 3. Розрахункові схеми в розрізі:

a - на початку видавлювання, б - в кінці видавлювання, в - після виймання пуансона, г - після виштовхування виробу з матриці

Силові режими видавлювання, виймання пуансона із здеформованої заготовки та виштовхування виробу з матриці показані на рис. 4. На рис. 4а представлена залежність зусилля видавлювання від переміщення пуансона. Зусилля на пуансоні постійно зростає і в кінці процесу видавлювання досягає 230 кН при переміщенні пуансона 13 мм. На рис. 4, б приведена залежність зусилля виймання пуансона із здеформованої заготовки від його зворотного переміщення. Зусилля інтенсивно зростає на початку виймання пуансона та складає максимальну величину 15 кН. Залежність зусилля виштовхування виробу з матриці від переміщення виштовхувача приведена на рис. 4, в. Максимальне зусилля виштовхування становить 14 кН. 


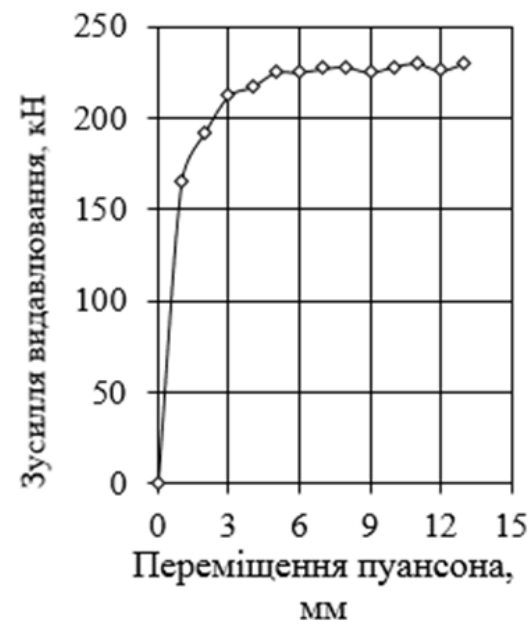

a

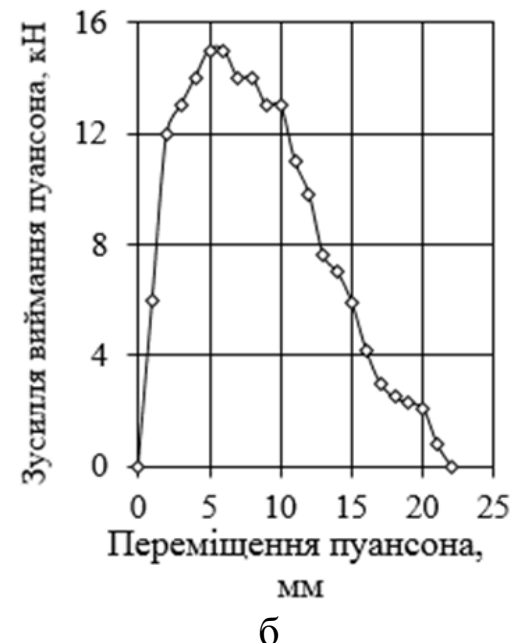

6

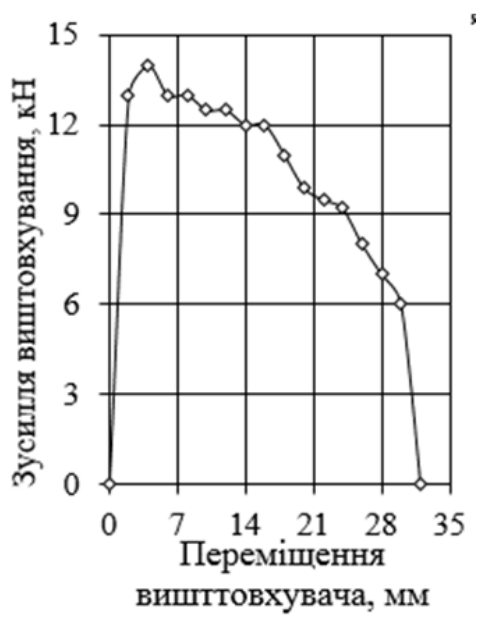

B

Рис. 4. Силові режими отримання виробу:

a - залежність зусилля видавлювання від переміщення пуансона; б - залежність зусилля виймання пуансона від його зворотного переміщення; в - залежність зусилля виштовхування виробу від переміщення виштовхувача

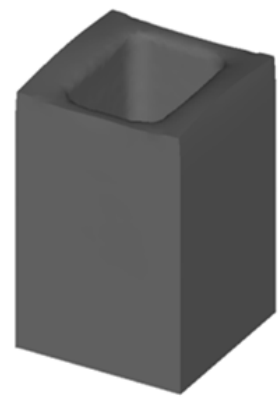

a

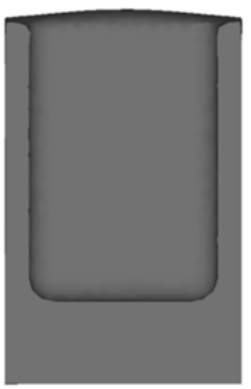

6

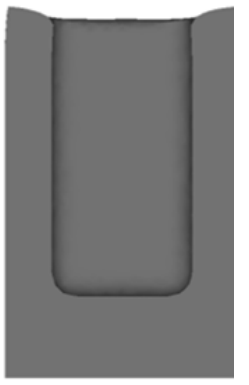

B

Рис. 5. Кінцеві форма та розміри виробу: стінки 4 мм

а - загальний вигляд; б - в розрізі по товщині стінки 2 мм; в - в розрізі по товщині

Кінцеві форма та розміри виробу показані на рис. 5. На рис. 5а зображений загальний вигляд виробу. Вигляди в розрізі по різних товщинах стінок показані на рис. 5, б і рис. 5, в. На всіх торцях стінок мають місце утяжини, а на торцях стінок 3 товщиною 2 мм утворюються виступи, що підтверджується експериментальними даними Свстратова В.О. [2].

Практичне значення мають розподіли нормальних напружень $\sigma_{n}$ на поверхнях здеформованої заготовки, які контактують з інструментом. По напруженнях $\sigma_{n}$ можна оцінити питомі зусилля і вони необхідні для проектування штампового оснащення. Розподіли напружень $\sigma_{n}$, що визначалися в перерізі по товщині стінки 2 мм по вісі пуансона, по висоті матриці та по вісі виштовхувача, зображені на рис. 6 . На рис. 7 показані такі розподіли, які визначені в перерізі по товщині стінки 4 мм. Порівнявши отримані графіки, можна зробити висновок, що величини нормальних напружень в перерізі по товщині стінок 2 мм та в перерізі по товщині 4 мм практично не відрізняються. Найбільші питомі зусилля на пуансоні виникають на початку переходу плоскої частини в радіус заокруглення і досягають величин у межах $\sigma_{n}=1760 \ldots 1832$ МПа. Для видавлювання пуансони можна виготовляти із сталей X12M, ШХ15. На поверхнях матриці максимальні значення цих напружень отримані у донних частинах ( $\left.\sigma_{n}=1200 \ldots 1300 \mathrm{MПа}\right)$. При таких розпираючих питомих зусиллях матриці необхідно виготовляти однобандажованими. На поверхнях виштовхувача найбільші напруження $\sigma_{n}=1570$ МПа виникають біля перетину вісей. 


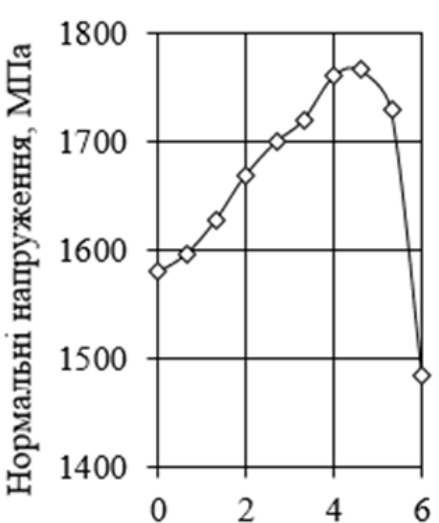

Розмір пуансона, мм

a

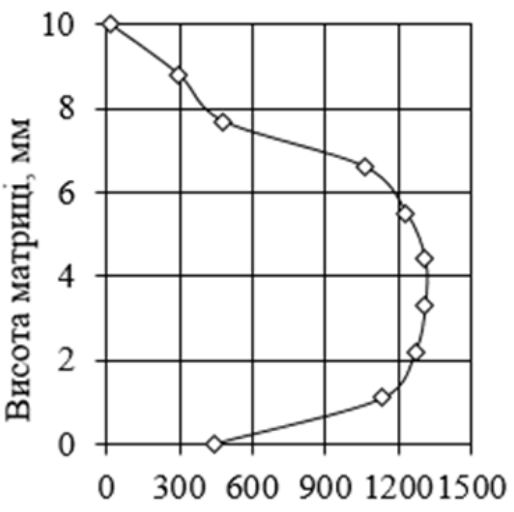

Нормальне напруження, МПIа

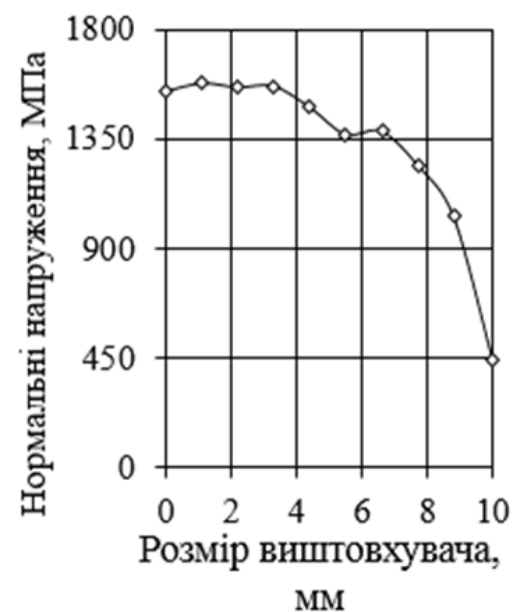

B

Рис. 6. Розподіли нормальних напружень на поверхнях інструменту в розрізі по товщині стінки 2 мм:

a - по вісі пуансона; б - по висоті матриці; в - по вісі виштовхувача

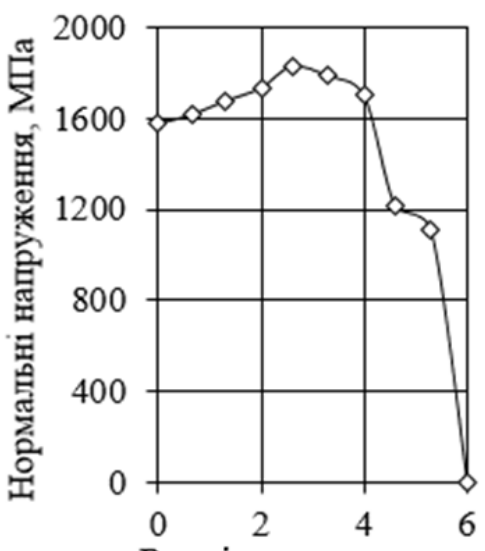

Розмір пуансона, мм

a

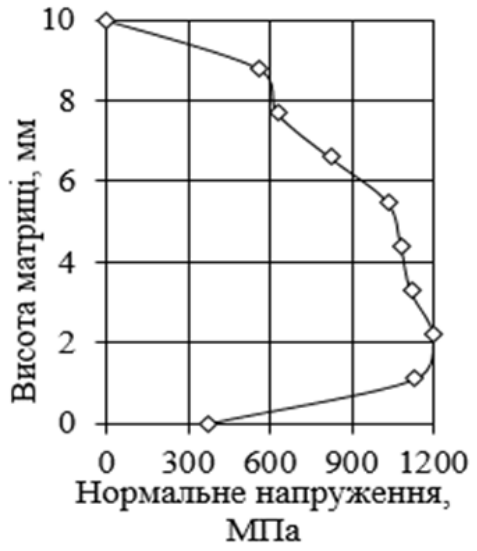

6

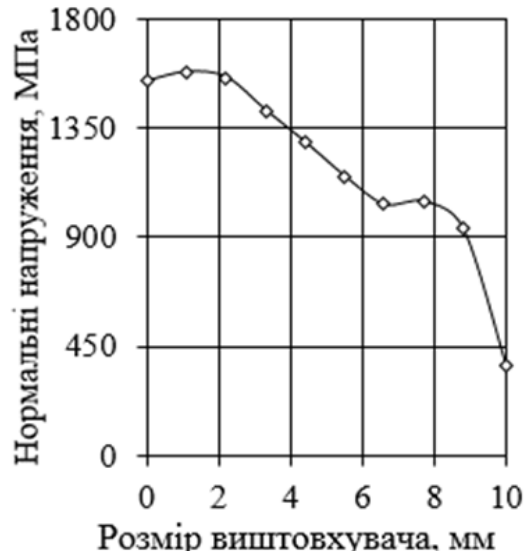

B

Рис. 7. Розподіли нормальних напружень в розрізі по товщині стінки 4 мм:

a - по вісі пуансона; 6 - по висоті матриці; в - по вісі виштовхувача

На рис. 8 показані розподіли компонент деформацій по об’єму виробу. На рис. 8, а показаний розподіл інтенсивності деформацій $\varepsilon_{i}$ в двох перерізах по вісях виробу. По ширині стінки розподіл нерівномірний. Інтенсивне пропрацювання структури металу отримують шари металу стінок зі сторони порожнини. У стінках товщиною 2 мм величини цих деформацій отримані у межах $\varepsilon_{i}=0,96 \ldots 1,5$. При таких величинах $\varepsilon_{i}$ у цій стінці по експериментальній діаграмі істинних напружень прогнозована межа текучості здеформованого металу складає $\sigma_{s}=380$ МПа. У стінках товщиною 4 мм отримано $\varepsilon_{i}=0,56 \ldots 1,5$, що забезпечує отримання величини $\sigma_{s}=350$ МПа. Пропрацювання пластичною деформацією донної частини виробу відбувається по всій висоті безпосередньо під пуансоном. У кутових зонах цієї частини метал практично не деформується. Найбільший внесок в інтенсивність деформацій у стінках вносять розтягувальні деформації в напрямку вісі , розподіл яких представлений на рис. 8, б. У стінках виробу товщиною 2 мм такі деформації знаходяться у межах $\varepsilon_{z}=0,52 \ldots 1,4$. А в стінках товщиною 4 мм отримано $\varepsilon_{z}=0,37 \ldots 1,1$. Величини розтягувальних деформацій $\varepsilon_{z}$ суттєво збільшують ступінь використання ресурсу пластичності здеформованого металу. 

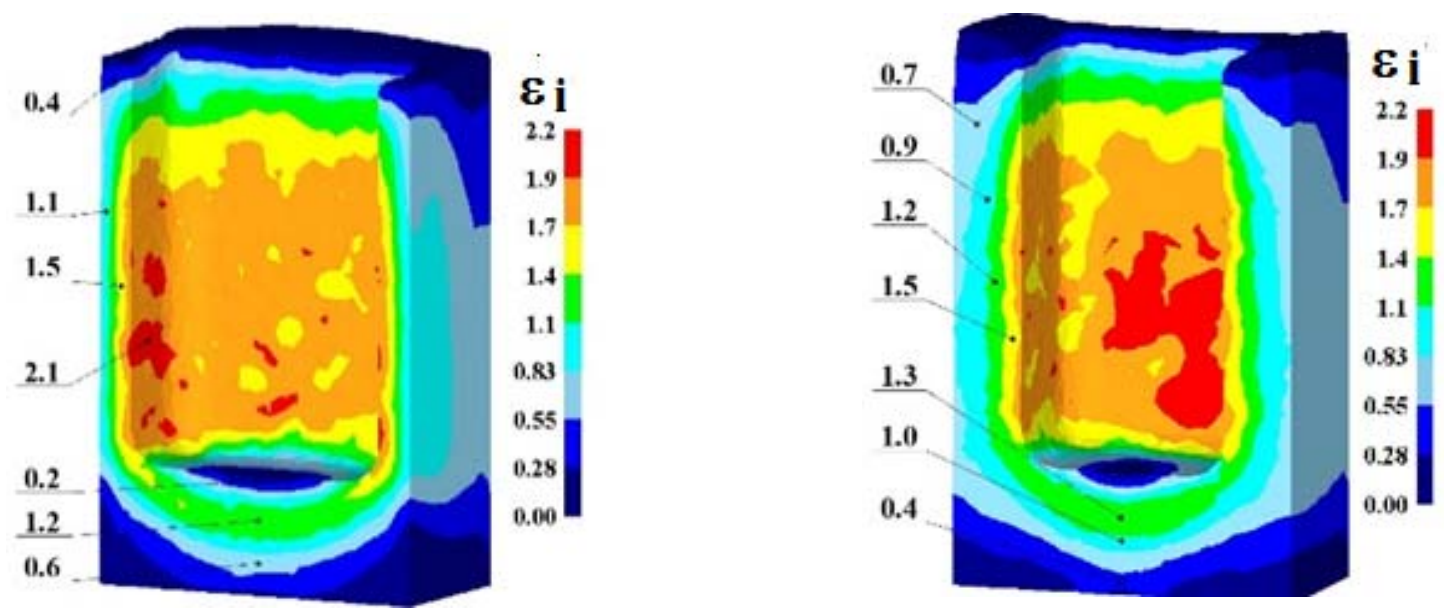

a
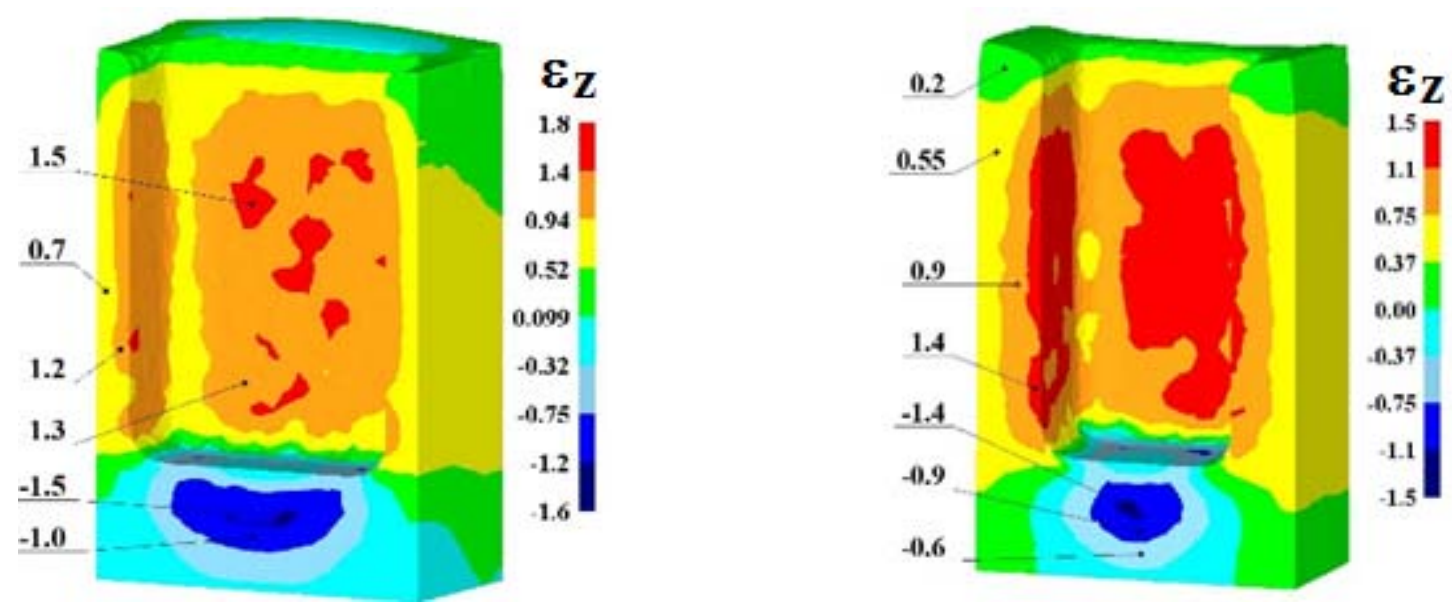

б

Рис. 8. Розподіли компонент деформацій в двох перерізах:

а - розподіл $\varepsilon_{i} ; \sigma$ - розподіл $\varepsilon_{z}$

На рис. 9 показані розподіли компонент напружень по об'єму виробу в кінці видавлювання. На рис. 9, а показаний розподіл інтенсивності напружень $\sigma_{i}$ в двох перерізах. Вигляди розподілів і величини цих напружень практично однакові. В осередку деформації під пуансоном отримано $\sigma_{i}=320-400$ МПа. По наведених значеннях $\sigma_{i}$ у цьому місці також можна прогнозувати величину межі текучості $\sigma_{s}$ здеформованого металу. Компоненти напружень в напрямку вісей координат в осередку деформації стискаючі. Найбільші величини по абсолютній величині отримані для напружень $\sigma_{z}$, розподіли яких в двох перерізах представлені на рис. 9, б. Вигляди розподілів і значення напружень майже не відрізняються. Безпосередньо під пуансоном отримано $\sigma_{z}=-1100 \ldots-1700$ МПа. У кутових зонах ці напруження досягають значень у межах $\sigma_{z}=-330 \ldots-890$ МПа.

Моделювання за допомогою МСЕ дозволило оцінити зміну температури здеформованого металу в процесі видавлювання. На рис. 10 зображені в двох перерізах розподіли температури у здеформованій заготовці в кінці видавлювання. Найбільша температура виникає в осередку деформації. Безпосередньо під пуансоном у донній частині отримано $T=81 \ldots 85^{\circ} \mathrm{C}$. Встановлені величини температури металу дозволяють уточнити вимоги до змащень, які використовуються при холодному видавлюванні виробів із алюмінію і його сплавів. 

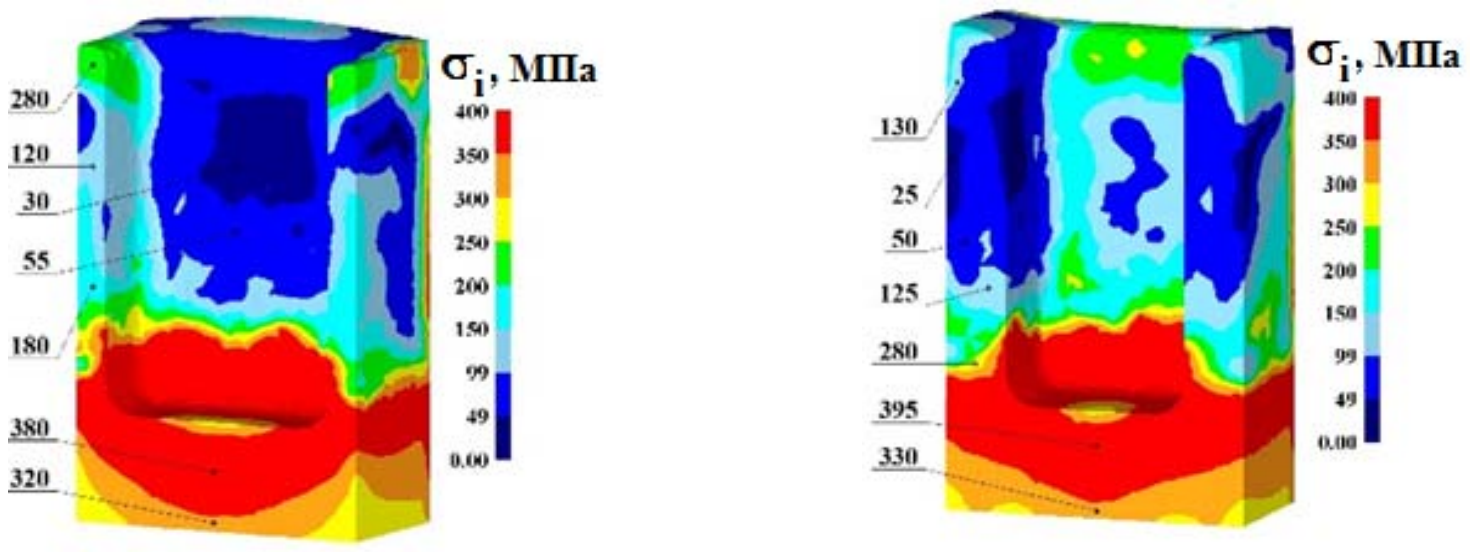

a
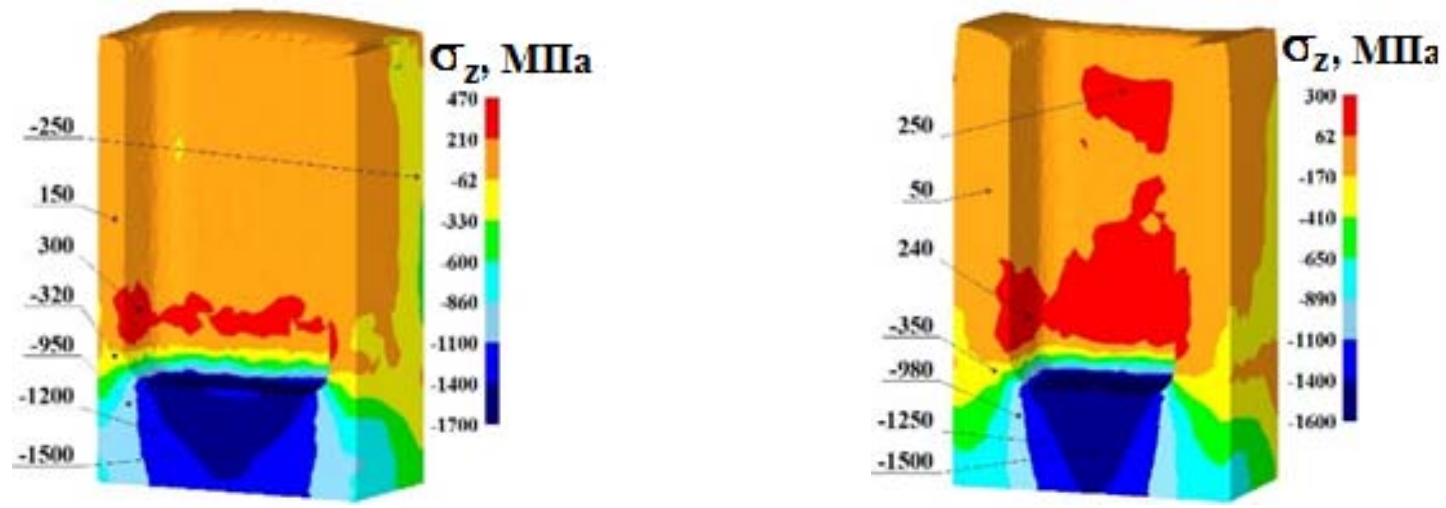

б

Рис. 9. Розподіли компонент напружень в двох перерізах:

a-розподіл $\sigma_{\dot{i}} ;$ б-розподіл $\sigma_{z}$
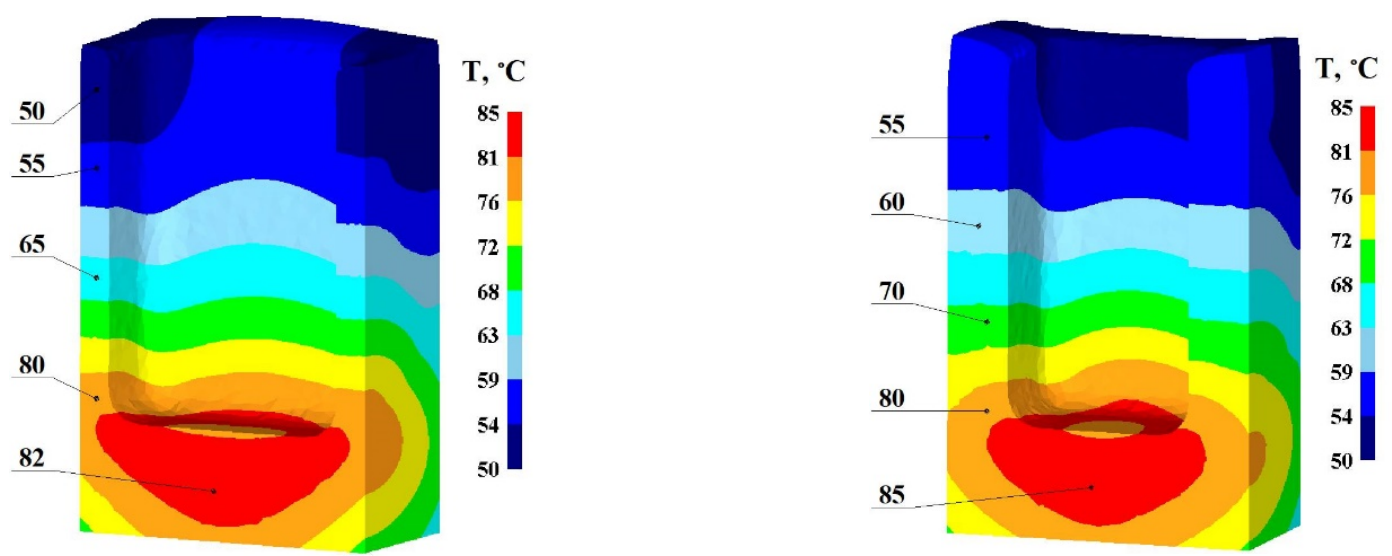

Рис. 10. Розподіли температури у двох перерізах здеформованої заготовки

\section{ВИСНОВКИ}

Методом скінченних елементів, з використанням пружно-пластичної моделі металу, проведений аналіз холодного видавлювання прямокутної порожнини в квадратній заготовці 3 пластичного алюмінію. Виконане моделювання безпосередньо процесу видавлювання, процесу виймання пуансона із здеформованої заготовки та процесу виштовхування виробу із матриці. Встановлені силові режими вказаних процесів, розподіли питомих зусиль на деформуючому інструменті при видавлюванні. Визначені кінцеві форма і розміри виробу. Виявленні напружено-деформований стан по об'єму виробу і зміна температури металу в процесі холодної формозміни. 


\section{СПИСОК ВИКОРИСТАНОЇ ЛІТЕРАТУРИ}

1. Гречников Ф. В., Дмитриев А. М., Кухарь В. Д. и др. Прогрессивные технологические процессы холодной штамповки. Под общ. ред. А.Г. Овчинникова. Москва: Машиностроение, 1985. 184 с

2. Евстратов В. А. Основы технологии выдавливания и конструирования. Харьков: Вища шк. изд-во при Харьк. ун-те. 1987. 144 с.

3. Семенов Е. И. и др. Ковка и штамповка: Справочник. В 4-х т. т.3. Холодная объемная штамповка. Под ред. Г.А. Навроцкого. Москва: Машиностроение, 1987. 384 с.

4. Семенов И. Е., Иванов А. В. Математическое моделирование процесса обратного выдавливания коробчатых деталей. Совершенствование процессов и оборудования обработки давлением в металлургии и машиностроении: Тематич. сб. научн. тр. Краматорск: ДГМА, 2007. С. 151-156.

5. Семёнов И. Е., Иванов А. В. Сравнение аналитических и численных методов расчета технологических параметров процесса, обратного выдавливания коробчатых деталей. Заготовительные производства в махиностроении. 2007. 12. С. 29-35.

6. Калюжний В. Л., Ніколенко М. С., Мельник О. В. Аналіз холодного зворотного видавлювання квадратних і прямокутних коробок із сталі і алюмінію. Вісник НТУУ «КПІ». Серія: Машинобудування. Київ: НТУУ «КПІ», 2011. 63. С. 112-117.

7. Семенов И. Е., Иванов А. В. Выдавливание коробчатых деталей с локальными активными силами трения. Фундаментальные и прикладные проблемы техники и технологии. Орел: ОГУ, 2019. 4-2 (336). С. $172-181$.

\section{REFERENCES}

1. Grechnikov F.V., Dmitriev A.M., Kuhar V.D. et al. Ed. A.G. Ovchinnikov. Progressive technological processes of cold stamping. Moscow: Mechanical Engineering. 1985, 184 p. (in Russian).

2. Evstratov V.A. Fundamentals of the technology of extrusion and design of dies. Kharkiv: High school. 1987, 144 p. (in Russian).

3. Forging and stamping. Handbook. In 4 t. T.3: Cold stamping. Ed. Navrotsky G.A. Moscow: Mechanical Engineering. 1987, 384 p. (in Russian).

4. Semenov I.E., Ivanov A.V. Mathematical modeling of the process of backward extrusion of box parts. Improving the processes and equipment of working by pressure in mechanical engineering and metallurgy. Kramatorsk: DSEA. 2007, pp. 151-156. (in Russian).

5. Semenov I.E., Ivanov A.V. Comparison of analytical and numerical methods for calculating the technological parameters of the process, reverse extrusion of box parts. Procurement in engineering. 2007, 12, pp. $29-35$. (in Russian).

6. Kalyuzhny V.L., Nikolenko M.S., Melnik O.V. Analysis of cold backward extrusion of square and rectangular boxes of steel and aluminum. Bulletin of NTUU "KPI". Series: Mechanical Engineering. 2011, 63, pp. $112-117$. (in Ukrainian).

7. Semenov I.E., Ivanov A.V. Extrusion of boxed parts with local active friction forces. Fundamental and applied problems of engineering and technology. Orel, OSU. 2019, 4-2 (336), pp. 172-181. (in Russian).

Калюжний В. Л. - д-р техн. наук, проф. НТУУ «КПІ ім. І. Сікорського»; E-mail: kwl_2011@ukr.net;

Марчук К. Л. - студент НТУУ «КПІ ім. І. Сікорського»; E-mail: kostiantyn.1.marchuk@gmail.com;

Левченко В. М. - канд. техн. наук, ст. наук. спів., докторант ДДМА, E-mail: goldange1271@gmail.com;

Дементєєв М. В - аспірант ДДМА.

НТУУ «КПІ ім. І. Сікорського» - Національний технічний університет України «Київський політехнічний інститут імені Ігора Сікорського», м. Київ.

ДДМА - Донбаська державна машинобудівна академія, м. Краматорськ. 